\title{
Knowledge Index of Women Goat Farmers in Various Aspirational Districts of Niti-Ayog in West Bengal, India
}

\author{
Bikash Santra, A. Goswami, K. C. Dhara, Sukanta Biswas* and Devi Prasanna Swain \\ Dept. of Veterinary \& A.H. Extension Education, Faculty of Veterinary \& Animal Sciences, \\ W.B. University of Animal \& Fishery Science, Kolkata-37, W.B., India \\ *Corresponding author
}

\begin{abstract}
A B S T R A C T
\section{Keywords}

Women, Goat

farming,

Knowledge,

Aspirational, Index, farmers

\section{Article Info}

Accepted:

07 November 2020

Available Online:

10 December 2020

The Goat farming is a significant contributor in rural economy and plays vital role to raise socio-economic status of the rural people especially to women folk. The Study was conducted on knowledge index of women goat farmers in purposively selected 05 nos. of aspiration districts, of NITI Aayog, GOI in W.B. A sample of 50 nos. of women goat farmers were randomly selected as respondents from each one block of each district with total sample size of 250 nos. for the present study. The collected data were compiled and analysed statistically with the help of pre-tested structured interview schedule for better interpretation of the findings of the study. The study explored that, improved technology for scientific goat rearing is essential for economic gain of stakeholders and farmers having land particularly agriculture land more than 2 acre and economically solvent were more knowledge score on goat rearing in the functional area. The Majority of Muslim community women goat farmer engaged as labour by occupation and nuclear family were having less knowledge on improved goat farming practices. The knowledge level about goat farming among these farm women need to be assessed for formulation of effective work plan in making sustainable livelihood, which is a promising endeavour in the aspirational districts of the state of West Bengal, India.
\end{abstract}

\section{Introduction}

Animal husbandry is a significant contributor in rural economy and plays vital role socioeconomic status of the rural people as a mean of employment provider, especially to women folk. With very less investments, goat rearing can be turned into a lucrative venture for women livestock owners. In India, about 70 percent of female work forces were engaged in livestock farming and women were key stakeholder for goat rearing in backyard system apart from their household works (Swaminathan, 1985). Goat farming has tremendous potential for income and employment generation, especially in rural areas (Singh et al., 2013). Knowledge is the body of information possessed by an individual or by a culture which is an intimate acquaintance of an individual with facts. Knowledge helps in adoption of any improved or new technology or practices many times. In aspirational districts, women are the major force to uplift the 
socioeconomic status for individual family particularly and society as a whole. Considering poverty, poor health, educational status and socio- economic characteristics in five aspirational districts namely-Birbhum, Nadia, Malda, South Dinajpur and Murshidabad as identified by the NITIAayog, Govt. of India in the state of West Bengal have been selected for the present study. In this backdrop of fact, an attempt has been made to "Study on knowledge index of women goat farmers in various aspirational districts of NITI-Aayog in West Bengal, India."

\section{Materials and Methods}

The present research work was pursued in purposively selected 05 nos. of aspirational districts, as identified by the NITI-Aayog, Govt. of India, considering its poverty, poor health, educational status and socioeconomic characteristics etc. in the state of West Bengal. A random sample of 50 number of women goat farmers were selected as respondents from block each district250 nos. for the present study. The dependent variable, namely- Knowledge index/level about improved Goat farming Practices along with seventeen (17) nos. of independent variables as-General, Socio-economic, Communication and socio-psychological characteristics were taken for analysis in the study. All the selected variables were measured either by established scale or test or by developing schedule.

The dependent variable i.e. Knowledge index/level was measured by using the available scales of Goswami (2010). The data were collected with the help of pre-tested structured interview schedule by the research himself and were compiled, tabulated and analysed statistically through the tools asMean \pm SE, chi-square, ANOVA \& correlation coefficient analysis.

\section{Results and Discussion}

The Knowledge Score (Mean \pm SE) generated using standard practice among the farm women in the aspirational districts of West Bengal in relation to improve farm practices of Goat husbandry had been depicted in the Table-1. Knowledge Score among the farm women of Nadia district $(37.37 \pm 1.66)$ was highest and in South Dinajpur (30.16 \pm 1.57$)$ was lowest than the other three districts viz Birbhum (35.07 \pm 1.75$)$, Malda (34.18 \pm 1.65$)$ and Murshidabad $(33.51 \pm 1.67)$. The result indicated that the farm women of Nadia district were having more knowledge about improved goat husbandry practices. As such no previous work had been done in the aspirational districts; the present results cannot be corroborated. More interestingly it had been found that, the farm women having agriculture land holding above 02 acres $(36.24 \pm 1.58)$ and having Pucca House $(36.5 \pm 1.48)$ or mansion $(37.1 \pm 1.82)$ were having more knowledge score about goat husbandry. Such findings were considered to be natural phenomenon of higher knowledge score as they preferred the improved technology. The farmers having land particularly agriculture land more than 2 acre and economically solvent were fond of farm animal rearing as a source of alternative family income. The improved technology for scientific goat rearing is essential for improvement of their economic gain and that's why knowledge Score was comparatively higher. The other factor like age, religion, occupation, education, caste, marital status, family size, house type had no impact on knowledge Score of those farm women. However, the present result was in tune with the finding of Goswami et al., (2014).

The Level of knowledge is an important factor to assess utilization of the improved technology among these farm women. The 
farm women engaged in goat farming were classified into three level of knowledge namely low $(<30)$, medium $(>30<35)$ and high ( $>35)$ It had been observed that, majority of farm women of Birbhum district(62\%) were low knowledge level other four districts. In Nadia districts (58\%) women goat farmers had low level of knowledge followed by medium (30\%) and high (12\%) level of knowledge improved goat farming practices. In Malda district, majority of (60\%) women goat farmers had low followed by medium $(30 \%)$ and high $(10 \%)$. The farm women having agriculture land holding above 2 acres and having Pucca House or mansion were found more in high or medium knowledge level about goat husbandry in comparison to others. Economic solvency was an important factor for acquiring knowledge apart from education of the farm women. The chi-square test in Table-1 revealed that, the difference in value in knowledge level of these farm women based on different category had a highly significant effect $(\mathrm{p}<0.01)$.
The knowledge level about goat farming among these farm women in these aspirational districts need to be assessed for formulation of effective work plan in making sustainable livelihood through goat rearing which was the prime intention of the currents study. The results indicated that a lot of gap can be filled by providing advanced technical knowledge to the women goat husbandry farmers which can bring about substantial change in their profit. Concurrent to the present findings, Luthra et al., (2019) in Haryana and Singhet al., (2020) in Punjab also reported low knowledge level of female famers engaged in goat rearing in their corresponding study areas. However, the reports of Kavithaa et al., (2014) contradict the present findings, probably due to the fact that the study involved SHG of Kerala. Singh et al., (2015) reported lacking of knowledge among the tribal farmers of Mandla and Seoni district of Madhya Pradesh during period.

Table.1 Knowledge Index (Mean \pm SE) and Knowledge Level of the Women Goat farmers in Aspirational districts of West Bengal

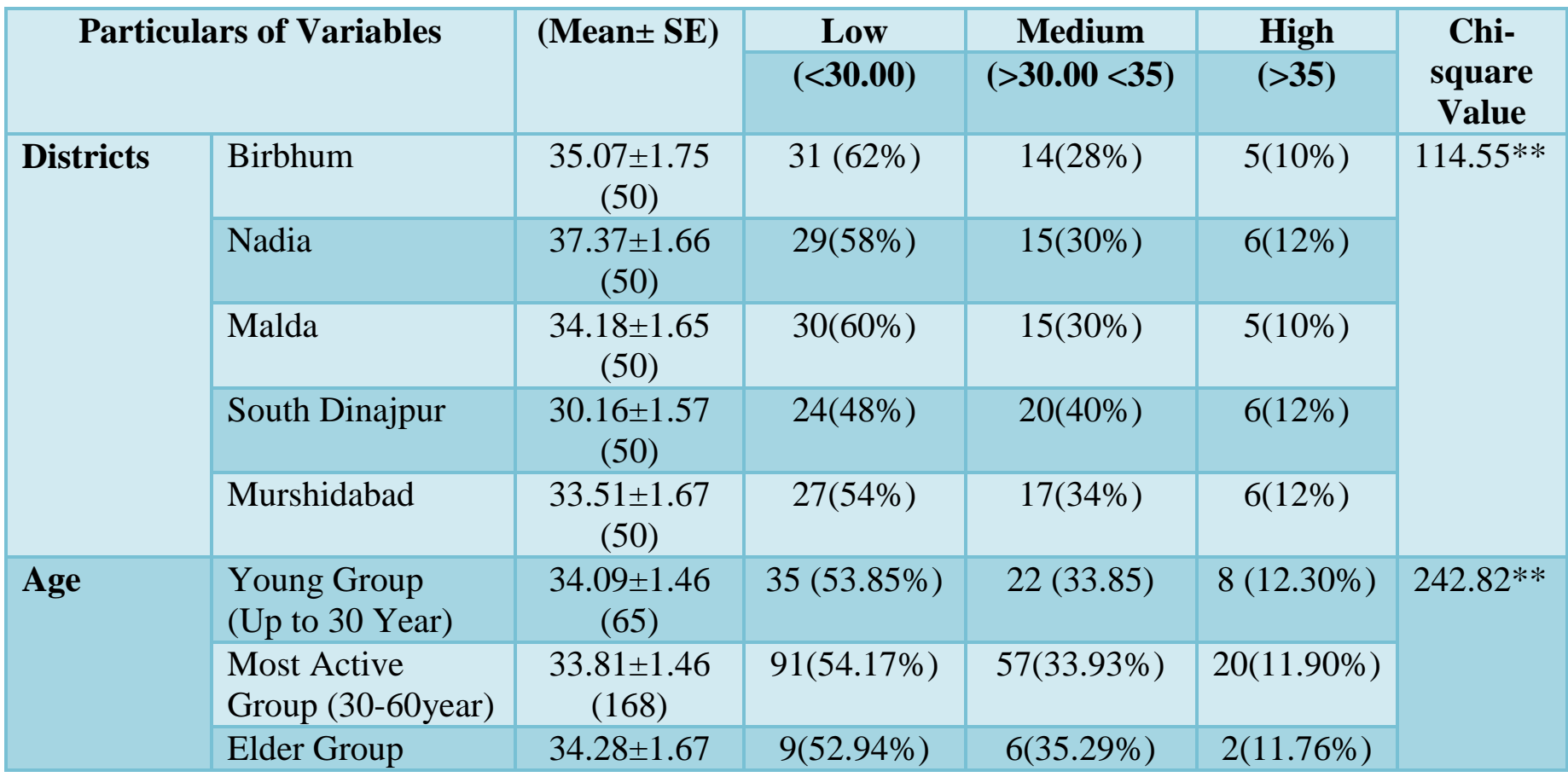




\begin{tabular}{|c|c|c|c|c|c|c|}
\hline & (Above 60 Year) & (17) & & & & \\
\hline \multirow[t]{2}{*}{ Religion } & Hindu & $\begin{array}{c}34.78 \pm 1.50 \\
\quad(195)\end{array}$ & $101(51.79 \%)$ & $71(36.41 \%)$ & $23(11.79 \%)$ & \multirow[t]{2}{*}{$144.15^{* *}$} \\
\hline & Muslim & $\begin{array}{c}34.51 \pm 1.69 \\
(55)\end{array}$ & $30(54.55 \%)$ & $18(32.73 \%)$ & $7(12.73 \%)$ & \\
\hline \multirow[t]{3}{*}{$\begin{array}{l}\text { Marital } \\
\text { status }\end{array}$} & Married & $\begin{array}{c}33.45 \pm 1.41 \\
(185)\end{array}$ & $100(54.05 \%)$ & $63(34.05 \%)$ & $22(11.89 \%)$ & \multirow[t]{3}{*}{$154.22 * *$} \\
\hline & Unmarried & $\begin{array}{c}34.74 \pm 1.58 \\
\text { (59) }\end{array}$ & $35(59.32)$ & $18(30.51)$ & $6(10.17)$ & \\
\hline & Widow/Widower & $\begin{array}{c}33.97 \pm 1.70 \\
\text { (6) }\end{array}$ & $4(66.67 \%)$ & $2(33.33 \%)$ & $0(0 \%)$ & \\
\hline \multirow[t]{5}{*}{$\begin{array}{l}\text { Occup- } \\
\text { ation }\end{array}$} & Labour & $\begin{array}{c}35.01 \pm 1.37 \\
(135)\end{array}$ & $81(60 \%)$ & $40(29.63 \%)$ & $14(10.37 \%)$ & \multirow[t]{5}{*}{$211.36^{* *}$} \\
\hline & Caste Occupation & $\begin{array}{c}35.63 \pm 2.16 \\
\text { (2) }\end{array}$ & $1(50 \%)$ & $1(50 \%)$ & $0(0 \%)$ & \\
\hline & Business & $\begin{array}{c}32.22 \pm 1.54 \\
\text { (16) }\end{array}$ & $10(62.50 \%)$ & $4(25 \%)$ & $2(12.50 \%)$ & \\
\hline & Independent & $\begin{array}{c}34.08 \pm 2.21 \\
\text { (2) }\end{array}$ & $1(50 \%)$ & $1(50 \%)$ & $0(0 \%)$ & \\
\hline & Cultivation & $\begin{array}{c}35.04 \pm 1.42 \\
(95)\end{array}$ & $55(57.89 \%)$ & $29(30.53 \%)$ & $11(11.51 \%)$ & \\
\hline \multirow[t]{4}{*}{ Caste } & General & $\begin{array}{c}34.85 \pm 1.82 \\
(85)\end{array}$ & $53(57.89 \%)$ & $23(30.53 \%)$ & $9(11.58 \%)$ & \multirow[t]{4}{*}{$125.45^{* *}$} \\
\hline & Schedule Caste & $\begin{array}{c}33.36 \pm 1.36 \\
(125)\end{array}$ & $72(62.35 \%)$ & $40(27.06 \%)$ & $13(10.59 \%)$ & \\
\hline & Schedule Tribe & $\begin{array}{c}32.98 \pm 1.38 \\
(24)\end{array}$ & $14(57.60 \%)$ & $7(32 \%)$ & $3(10.40 \%)$ & \\
\hline & OBC & $\begin{array}{c}35.19 \pm 2.12 \\
(16)\end{array}$ & $9(58.33 \%)$ & $5(29.17 \%)$ & $2(12.50 \%)$ & \\
\hline \multirow{7}{*}{$\begin{array}{l}\text { Education } \\
\text { of } \\
\text { farm } \\
\text { women }\end{array}$} & Illiterate & $\begin{array}{c}35.55 \pm 1.51 \\
(48)\end{array}$ & $31(64.58 \%)$ & $13(27.08 \%)$ & $4(8.33 \%)$ & \multirow[t]{7}{*}{$147.25^{* *}$} \\
\hline & Can Read Only & $\begin{array}{c}33.61 \pm 1.61 \\
\text { (6) }\end{array}$ & $4(66.67 \%)$ & $1(16.67 \%)$ & $1(16.67 \%)$ & \\
\hline & Can Read \& Write & $\begin{array}{c}33.65 \pm 1.47 \\
(48)\end{array}$ & $29(60.42 \%)$ & $14(29.17 \%)$ & $5(10.42 \%)$ & \\
\hline & Primary & $\begin{array}{c}33.07 \pm 1.51 \\
\text { (39) }\end{array}$ & $22(56.41 \%)$ & $12(30.77 \%)$ & $5(12.82 \%)$ & \\
\hline & Middle School & $\begin{array}{c}33.76 \pm 1.58 \\
\text { (29) }\end{array}$ & $16(55.17 \%)$ & $8(27.59 \%)$ & $5(17.24 \%)$ & \\
\hline & High School & $\begin{array}{c}34.03 \pm 1.48 \\
\text { (75) }\end{array}$ & $40(53.33 \%)$ & $25(33.33 \%)$ & $10(13.33 \%)$ & \\
\hline & Graduate & $\begin{array}{c}36.2 \pm 1.82 \\
\quad(5)\end{array}$ & $2(40 \%)$ & $2(40 \%)$ & $1(20 \%)$ & \\
\hline $\begin{array}{l}\text { Family } \\
\text { type }\end{array}$ & Nuclear Family & $\begin{array}{c}33.75 \pm 1.14 \\
(212)\end{array}$ & $130(61.32 \%)$ & $62(29.25 \%)$ & $20(9.43 \%)$ & $106.55^{* *}$ \\
\hline
\end{tabular}




\begin{tabular}{|c|c|c|c|c|c|c|}
\hline & Joint Family & $\begin{array}{c}34.1 \pm 1.20 \\
\text { (38) }\end{array}$ & $18(47.37 \%)$ & $15(39.47 \%)$ & $5(13.16 \%)$ & \\
\hline \multirow[t]{2}{*}{$\begin{array}{l}\text { Family } \\
\text { Size }\end{array}$} & Small & $\begin{array}{c}33.77 \pm 2.18 \\
(183)\end{array}$ & $110(60.11 \%)$ & $55(30.05 \%)$ & $18(9.84 \%)$ & \multirow[t]{2}{*}{$109.27 * *$} \\
\hline & Medium & $\begin{array}{c}33.45 \pm 1.24 \\
\text { (67) }\end{array}$ & $39(58.21 \%)$ & $21(31.34 \%)$ & $7(10.45 \%)$ & \\
\hline \multirow[t]{6}{*}{$\begin{array}{l}\text { House } \\
\text { Type }\end{array}$} & No house & $\begin{array}{c}33.28 \pm 1.61 \\
(26)\end{array}$ & $15(57.69 \%)$ & $8(30.77 \%)$ & $3(11.54 \%)$ & \multirow[t]{6}{*}{$192.65 * *$} \\
\hline & Hut & $\begin{array}{c}33.65 \pm 1.47 \\
(55)\end{array}$ & $30(54.55 \%)$ & $20(36.36 \%)$ & $5(9.09 \%)$ & \\
\hline & Kutcha House & $\begin{array}{c}34.06 \pm 1.51 \\
(46)\end{array}$ & $25(54.35 \%)$ & $16(34.78 \%)$ & $5(10.87 \%)$ & \\
\hline & Mixed House & $\begin{array}{c}34.77 \pm 1.58 \\
(42)\end{array}$ & $24(57.14 \%)$ & $13(30.95 \%)$ & $5(11.90 \%)$ & \\
\hline & Pucca House & $\begin{array}{c}36.5 \pm 1.48 \\
(78)\end{array}$ & $42(53.85 \%)$ & $27(34.62 \%)$ & $9(11.54 \%)$ & \\
\hline & Mansion & $\begin{array}{l}37.1 \pm 1.82 \\
\text { (3) }\end{array}$ & $2(66.67 \%)$ & $1(33.33 \%)$ & $0(0 \%)$ & \\
\hline \multirow[t]{4}{*}{$\begin{array}{l}\text { Land } \\
\text { Holding }\end{array}$} & No land/Land less & $\begin{array}{c}33.36 \pm 1.52 \\
(52)\end{array}$ & $31(59.62 \%)$ & $16(30.77 \%)$ & $5(9.62 \%)$ & \multirow[t]{4}{*}{$128.35^{* *}$} \\
\hline & Up to 1 hectare & $\begin{array}{c}34.52 \pm 1.43 \\
(99)\end{array}$ & $57(57.58 \%)$ & $32(32.32 \%)$ & $10(10.10 \%)$ & \\
\hline & Up to 2 hectares & $\begin{array}{c}35.12 \pm 1.42 \\
(73)\end{array}$ & $39(53.42 \%)$ & $23(31.51 \%)$ & $11(15.07 \%)$ & \\
\hline & Above 2 hectares & $\begin{array}{c}36.24 \pm 1.41 \\
\text { (26) }\end{array}$ & $11(42.31 \%)$ & $11(42.31 \%)$ & $4(15.38 \%)$ & \\
\hline
\end{tabular}

Significance levels: $* \mathrm{P}<0.05 * * \mathrm{P}<0.01$

Table.2 ANOVA of Knowledge Index of the Women Goat Farmers of aspirational Districts of NITI-Ayog in West Bengal

\begin{tabular}{|l|c|c|c|}
\hline Source of variance & df & Mean Square & F \\
\hline District & 4 & 11.743 & 0.539 \\
\hline Age & 4 & 3.658 & 0.168 \\
\hline Religion & 2 & 6.351 & 0.292 \\
\hline Marital Status & 2 & 10.246 & 0.471 \\
\hline Occupation & 4 & 21.177 & 0.973 \\
\hline Education & 6 & 4.316 & 0.198 \\
\hline Family Size & 4 & 13.628 & 0.626 \\
\hline Family Type & 2 & 1.047 & 0.048 \\
\hline Category & 3 & 6.526 & 0.300 \\
\hline Land Holding & 4 & 13.375 & 0.614 \\
\hline
\end{tabular}


Table.3 Spearman Correlation of Knowledge Level of Women Goat Farmers in Aspirational Districts of NITI-Aayog in West Bengal, India

\begin{tabular}{|c|c|c|c|c|c|c|c|c|c|c|c|c|}
\hline Variables & District & Age & Religion & $\begin{array}{c}\text { Marital } \\
\text { status }\end{array}$ & Occupatior & Caste & Education & $\begin{array}{l}\text { Family } \\
\text { type }\end{array}$ & $\begin{array}{c}\text { Family } \\
\text { Size }\end{array}$ & $\begin{array}{c}\text { House } \\
\text { Type }\end{array}$ & $\begin{array}{l}\text { Land } \\
\text { Holding }\end{array}$ & $\begin{array}{c}\text { Know. } \\
\text { Level }\end{array}$ \\
\hline Districts & 1.0 & $-0.158 *$ & $0.142 *$ & $-.640 * *$ & $0.383 * *$ & $.301 * *$ & $-.628 * *$ & 0.0 & $-.290 * *$ & $.234 * *$ & -0.1 & $-0.137 *$ \\
\hline Age & & 1.0 & 0.0 & $.164 * *$ & -0.1 & $-0.396 * *$ & $.150 *$ & 0.1 & 0.1 & 0.0 & 0.1 & 0.001 \\
\hline Religion & & & 1.0 & $-.269 * *$ & $.403 * *$ & $0.127^{*}$ & $.333 * *$ & $.418 * *$ & $.170 * *$ & -0.1 & 0.0 & $-0.336 * *$ \\
\hline $\begin{array}{l}\text { Marital } \\
\text { status }\end{array}$ & & & & 1.0 & $-.358 * *$ & $-0.223 * *$ & $.528 * *$ & -0.1 & $.245 * *$ & $-.218 * *$ & $.317 * *$ & $0.220 * *$ \\
\hline Occupation & & & & & 1.0 & $0.444 * *$ & 0.0 & $.353 * *$ & 0.1 & 0.0 & $.353 * *$ & $-0.242 * *$ \\
\hline Caste & & & & & & 1.0 & $-.153 *$ & 0.1 & 0.01 & 0.1 & $0.203 * *$ & -0.109 \\
\hline Education & & & & & & & 1.0 & $0.267 * *$ & $0.407 * *$ & $-.337 * *$ & $0.401 * *$ & -0.108 \\
\hline $\begin{array}{l}\text { Family } \\
\text { type }\end{array}$ & & & & & & & & 1.0 & $0.608 * *$ & 0.1 & $0.125^{*}$ & $-0.258 * *$ \\
\hline $\begin{array}{l}\text { Family } \\
\text { Size }\end{array}$ & & & & & & & & & 1.0 & -0.1 & $0.248 * *$ & -0.058 \\
\hline $\begin{array}{l}\text { House } \\
\text { Type }\end{array}$ & & & & & & & & & & 1.0 & $-0.323 * *$ & 0.094 \\
\hline $\begin{array}{l}\text { Land } \\
\text { Holding }\end{array}$ & & & & & & & & & & & 1.0 & 0.024 \\
\hline $\begin{array}{l}\text { Knowledge } \\
\text { Level }\end{array}$ & & & & & & & & & & & & 1.0 \\
\hline
\end{tabular}


Analysis of variance in respect of District, Age of Farm Women, Religion, Marital Status, Occupation, Caste, Education of Farm Women, Family Type, Family Size, House Type and Land Holding Capacities had been presented in Table-2. It had been observed that, there was no significant effect of all the variables like districts, age of the farm women, religion, marital status, occupation, caste, education of farm women, family type, family size, house type and land holding capacities on knowledge score.

The Correlation Co-efficient(Spearman) of each of the personal and socio-economic characteristics with the knowledge level of respondent have been furnished in Table 3. The study depicted that, overall in five districts out of 11 independent variables, religions, occupation and family type showed negatively correlated and varied significantly ( $p<0.01)$ with knowledge level of women goat farmers, whereas district showed negatively correlated with significant $(\mathrm{p}<0.05)$ variation with the knowledge level of women goat farmer in five aspirational districts of West Bengal. The remaining six variables viz., Age, Caste, Education, Family Size, House Type and Land Holding did not establish any significant relationship with the knowledge level of women goat farmers in five aspirational districts in West Bengal. It may be concluded that majority of nuclear family and Muslim women goat farmer were having less knowledge about improved goat farming practices. The women goat farmers, who were engaged as labour by occupation was less knowledge regarding improved goat farming practices. These findings are like in tune with findings of Goswami (2014) which considering being the normal scenario of West Bengal.

In conclusions the Goat farming is a significant contributor in rural economy and plays vital role to raise socio-economic status of the rural people especially to the women farmers. The study on knowledge index of women goat farmers in various aspiration district of NITI-Aayog in West Bengal explore that, improved technology for scientific goat rearing is essential for economic gain of stakeholders and farmers having agriculture land more than 2 acre and economically solvent were more knowledge score on goat rearing as a source of alternative family income. The other factors like age, religion, occupation, education, caste, marital status, family size, house type had no impact on knowledge score of those farm women. The findings were considered to be natural phenomenon of higher knowledge score as they preferred the improved technology. Majority of nuclear family and Muslim community women goat farmer engaged as labor by occupation were having less knowledge regarding improved goat farming practices. The knowledge level about goat farming among these farm women in these aspirational districts need to be assessed for formulation of effective work plan in making sustainable livelihood through goat rearing which is a promising endeavor in the study area of the state of West Bengal, India.

\section{References}

Goswami, A. (2010). The Impact of Extension Education on the Social, Psychological and administrative behaviour of the livestock owners of the Sundarbans, West Bengal. Ph.D. thesis submitted to the University of Kalyani, West Bengal.

Goswami, A., Roy, N., Mazumdar, A.K. and Duttagupta, R. (2014). Behavioural study of the livestock owners to enhance the productivity in saline belt of Sundarban, West Bengal. Indian Journal of Animal Health, 39(2): 42-46.

Kavithaa, N.V., Jiji R.S. and Rajkumar N.V.(2014). Knowledge and attitude of 
the members of women self - help groups in goat farming in Thrissur district, Int. J. Sci., Environ. Technol., 3(1):198-202.

Prince, L., Singh, S.P., Sangwan, S.S. and Anika, M., (2019). Knowledge of farmers about recommended goat rearing practices in Haryana. Haryana Vet., 58(1):30-35.

Singh, M., Dubey, M.K. and Khare, Y.R. (2013). Factors effecting adoption of dairy management practices by members of DCS. Indian Research Journal of Extension Education, 3(7): 25.

Singh, R., Gour, S. and Mandal, M. K.
(2015). Assessment of knowledge level of tribal farmers regarding scientific animal husbandry practices of Madhya Pradesh. 4th International Conference on Agriculture \& Horticulture July 1315, 2015 Beijing, China, 4(2):80.

Singh, S., Kasrija, R., and Singh, P. (2020). Determination of knowledge level of goat farmers about breeding practices in Punjab. Journal of Entomology and Zoology Studies; 8(2):198-200.

Swaminthan, M. S. (1985). Imparting of rural Women user's perspective to Agril. Research and Development, IRRI, Philippines.

\section{How to cite this article:}

Bikash Santra, A. Goswami, K. C. Dhara, Sukanta Biswas and Devi Prasanna Swain. 2020. Knowledge Index of Women Goat Farmers in Various Aspirational Districts of Niti-Ayog in West Bengal, India. Int.J.Curr.Microbiol.App.Sci. 9(12): 625-632.

doi: https://doi.org/10.20546/ijcmas.2020.912.074 